\title{
A Rustic Opinion about Construction of Ideological and Political Education in Colleges and Universities
}

\author{
Zhanlu Xu \\ Zhejiang University \\ Hangzhou, China 310028 \\ Qian Jiang Academy of Hangzhou Normal University \\ Hangzhou, China 310032
}

\begin{abstract}
Constructivism is based on the theory that "cognition is formed in the interaction of subject and object", which accords with Marx's epistemology; Constructivism takes the initiative and consciousness of subject of education as the core, which has the significance of axiology to the initiative of college students in ideological and political education Constructivism takes the active constructive, social interaction and situational learning methods as a guide, and based on the problem-based teaching (also known as anchored instruction) as an important principle of teaching, which has important methodological significance for students to learn ideological and political education content and ideological and political theory teaching.
\end{abstract}

Keywords-colleges and universities; the ideological and political education; constructivism

\section{INTRODUCTION}

Under the condition of today's real society, economic globalization and the development of the market system which caused the damage to the national spirit, facing the international competition and domestic development trend in China, the social competition circumstances were spontaneous desalt in spiritual value orientation, and caused part of the ideological and political education in colleges and universities to ignore the long term, the global interests utilitarian tendency, the tendency of value rationality.[1]Based on this, the ideological and political education in colleges and universities should "further strengthen its guidance function, establish scientific guiding principle, adopt the appropriate way, and chose targeted guidance content, improve the quality of the education guidance."[2]Constructivism ideas stems rising from the 20th century that advocated: knowledge was not the objective characterization of the real world, but in interacting with the scene construction for the interpretation of the world, the process of construction including "situation", "session", "collaboration" and "meaning construction".[3]Therefore, the teachers and students were equal participants and learners in the process of learning, students were constructing knowledge actively, teachers were significance to construct the helper and facilitator, which cognitive theory was increasingly accepted, respected. It is reference significance for the innovation and development of ideological and political education.

\section{INSPIRING CONSTRUCTIVISM THEORY}

\section{A. The Unity and Opposites: Marxist Materialist Theory of Reflection and Constructivism Epistemology}

1) The unity of opposites on the epistemological philosophy: Constructivism theory comes from Kant's philosophy, he stressed that "human innate sensibility intuitive form of phenomenon form of the construction of object function and category of knowledge about the object of the arrangement particular emphasis on the objectivity of object that was the construction of transcendental subject".[4]Later, constructivism revealed the understanding of Hegel's historic. This laid the groundwork for the further development of Marx's theory of cognitive. Kant and Hegel overthrew the original philosophical tradition and understanding of people carried on the thorough research, part of his idea had become an important theory of Marxist materialist theory of reflection, epistemological basis, they were the same in the field of value subject's active role. Marx's view of cognition started from the philosophy foundation, laying particular stress on general abstractness of philosophy, the key was to know which was primary problems between and existence; Kant and Hegel in a more, more in-depth understanding of how to produce, how to implement, from another point of view to help people better understanding the knowledge itself, I think that they have a little cross, but more is different in the height, angle and level.

2) Coupling in psychological viewpoint: The psychological basis of constructivism theory mainly come from Piaget's cognitive construction theory and Vygotsky's "theory of culture and history ","theory of the zone of proximal development", and its social construction thought. Piaget developed "genetic epistemology" and denied the structure of the apriority, realized the combination of understanding philosophy and psychology research, thought that the relationship between subject and object were mutual restriction, ${ }^{[4]}$ There were similarities on His point of view and Marxism's theories that dialectical materialist theory of reflection and contradiction movement rule and the 
regularity of inside and outside. Vygotsky's psychological development theory of "cultural history" and "the theory of the zone of proximal development" attached great importance to the social activities and interactions of language and the individual in the person's important role in the development of psychology. ${ }^{[6]}$ This is consistent with the view of Marxist historical materialism, both emphasized the social nature of people.

\section{B. Internal Communication: Demand for Ideological and Political Education in College Students and Constructivism Theory of Actively Learning}

Marx defined the nature of human as: "we were not single person inherent abstraction, in reality; it was the sum of all social relations". [7]This suggested that people were social, in addition to the survival of the natural instinct, there was also a "instinct" social ability of learning to adapt to society, these capabilities included the code of ethics, ideology, political views. Constructivism learning theory believed that learning was a process of students constructing their knowledge actively. The theory put forward: learning was the practice including interactive intentions - action activities, therefore, the study was the need of will, intentional, active, conscious and construction practice.[8]Motivation was the direct cause of human activities, Therefore, based on the requirement of young college students to the ideological and political education content, Using constructivism active initiative and selfconsciousness and procedural characteristics can better realize the value of ideological and political education. In addition, young college students, on the one hand, with the main body of social practice, on the other hand, school, family, employment, under the pressure, the ideological and political education had both internal and external motivation, therefore, the ideological and political education for college students had intrinsic demand, this was also the embodiment of the ideological and political education in colleges and universities which can be constructive.

\section{Perfecting Improving: Using the Methods of Constructivist Learning and Teaching}

1) Using the methods of constructivist learning: For college students, the learning of moral concept, ideology, political views were necessity with inner and outer, and were also a process of continuous learning. Constructivism learning theory fully emphasized the active constructive of learning, social interaction, and situational, put forward the theories such as cognitive apprenticeship, community of practice learning. Brown found that apprentices can learn more effectively with the help of skilled instructors through the learning situation in which the skilled instructors assigned real tasks to the apprentices.[9]In the process of ideological and political education, according to the different educational content, educators can guide the education object involved in the education activities, let the students become the important participants of ideological and political education and not just be the bystanders, listeners.
At the same time, we can set peer models to college students on feeling moral learning and ideological change, which can enhance students' initiative education activities, also can enhance the effect of education. Lave and Wender insisted that learning practice not only happened in a real-world scenario, more important was happening in the community of practice, further emphasized the social and cultural attributes, it was called learning community of practice.[10]The content of the ideological and political education of many aspects need to let the students own actual "immersive" to understand and master, we can try to rely on student organization, community, platform structures, such as the moral education thought and theory practice lesson learning community, enriching campus culture and promoting the moral education work.

2) Using the mode of constructivist teaching: Problem Based on learning (PBL), also called anchored instruction, it was one of the important principles of constructivism teaching, The principle deemed: "putting forward problems designed by the teacher or the cooperation between teachers and students ,organizing students to investigate and explore by focusing problems, just for the students understanding the thinking and problems solving process, mastering the related concepts and knowledge, can further developed students' ability of understanding, analysis, solving problems, eventually formed students' independent consciousness and abilities.[11]This kind of teaching mode to cultivate students' autonomous learning, explore learning process and to grasp the concept of flexible and knowledge as the goal, to grasp the concept of flexible and knowledge as the goal, to students' ability to solve problems, the ability to organize and coordinate team members, exploration survey ability as the evaluation standard, other countries in basic education stage and vocational education and other fields had been widely applied and obtained more satisfactory results. Constructivist teaching methods were in order to clear learning objectives (problem) as the breakthrough point, on the basis of the teachers' teaching design and providing information resources, situation for auxiliary, students' independent inquiry and finding and solving problems as the core, just to achieve " learning by doing".[8]This kind of teaching goals were to build a community of knowledge construction, in which learners around issues of common concern discussed and explored, to form relevant insights, and published the insights in the community public space in public, and through continuous discussion, improvement, rich content, to relate to new questions. In ideological and political theory course, by the way of knowledge community, adopting problem-based learning methods, guided students to play to the subjectivity in ideological and political theory course, guided students to reflect social reality, explored the social hot spots to identify socialist core values. 


\section{CONCLUSION}

The education concept and education objective are in common between constructivism and the ideological and political education. We can use learning methods and teaching methods for reference of constructivist. Will, of course, there are many theoretical and practical problems in constructivism, the effect must be tested through social practice.

\section{REFERENCES}

[1] [1]Yongting Zheng.Times Subject for the Ideological and Political Education.China Higher Education,(2003) No.21, p. 13-14.

[2] Ruiyan Guo,Da Chai. Thinking about Strengthening Ideological and Political Education Function in the new period.Leading Journal of Ideological \& Theoretical Education,(2013) No.7, p. 99.

[3] Jianwei Zhang,Yanqing Sun.From the "Learning by Doing" to Constructivism:Exploring the Path of Learning Theories.Theory and Practice of Education,(2006) No.7, p. 35.

[4] Junya Yuan.Constructivism: from Kant, Hegel to Marx.Journal of Fujian Provincal Committee Party School of CPC.(2011)No.2, p. 5.

[5] Jean Piaget.The Principes of Genetic Epistemology.The Commercial Press, 1997,p.81.

[6] Zhenqiu Yu.Wei Guo Ci Ji Jiao Yu Lun Zhu Xuan.People's Education Press, 1994,p.88.

[7] Selections (Anthologies) of Marx and Engels.People's Publishing House.1995,p.56.

[8] Xianglin Zhao,Chengxu Wang.Du Wei Jiao Yu Lun Zhu Xuan.East China Normal University Press, 1981,p.248.

[9] Brown, J.S., Collins, A. and Duguid, P. (1989) Situated Cognition and the Culture of Learning. Educational Researcher, 18, 32-42.

[10] Jean Lave \& Etienne Wender(1991).Situated Learning:Legitimate Peripheral Participation. Cambridge University Press.UK:49.

[11] CE Hmelo.The Development of Self-directed Learning Strategies in Problem-based Learning.International Conference on Learning Sciences, 1996,P.421-426. 